\title{
Rapid and Efficient Synthesis of Hydroxytriarylmethanes under Ultra Sonic Irradiation Using Keggin Heteropolyacids and Preyssler Catalysts in Green Conditions
}

\author{
Hooshang Hamidian \\ Department of Chemistry, Payame Noor University (PNU), 19395-4697 Tehran, Iran \\ Correspondence should be addressed to Hooshang Hamidian; hooshanghamidian@yahoo.com
}

Received 25 September 2012; Revised 26 November 2012; Accepted 18 December 2012

Academic Editor: Dipakranjan Mal

Copyright (C) 2013 Hooshang Hamidian. This is an open access article distributed under the Creative Commons Attribution License, which permits unrestricted use, distribution, and reproduction in any medium, provided the original work is properly cited.

A new synthesis of hydroxytriarylmethane derived from the reaction of 2-sulfobenzoic anhydride and phenols in the presence of heteropolyacids as green, reusable, and efficient catalyst (using catalytic amount) under ultrasonic irradiation is reported in this paper.

\section{Introduction}

Triarylmethanes (TAMs) are highly colored materials and have been used as dyes and pigments for a very long time [1]. They have received much attention and have been widely used for many purposes such as for photochromic agents [2], protective groups [3], building blocks for dendrimers and NLOs $[4,5]$. Some triarylmethanes have shown a wide range of pharmaceutical properties such as antioxidant, antivirus, and antitumor activities $[6,7]$.

Two basic methods to synthesize triarylmethanes (TAMs) are the Grignard reaction of various carbonyl compounds like benzophenone and methyl benzoate, and the aromatic electrophilic substitution reaction in acidic media $[8,9]$. Symmetric triarylmethanes (TAMs) were prepared by the treatment of electrophilic reagents such as triethyl orthoformate or chloroform with arene nucleophiles $[10,11]$.

Recently, an efficient synthesis of unsymmetrical triarylmethanes has been reported by Friedel-Crafts reaction of aromatic nucleophiles with heteroarylcarbinols [12]. Werbel et al. have reported a facile method for the synthesizing of triarylmethane by the catalytic hydrogenation of the diaryl ketone and the subsequent treatment of the carbinol with aryl amines and $\mathrm{HCl}[13]$.
The selective condensation of oxophilic metal phenolates with an aromatic aldehyde at the ortho position of the starting phenol has been utilized in the synthesizing of a $2,2^{\prime}$-dihydroxy triphenylmethane, another TAM derivative [7].

Development of methods using heteropolyacids (HPAs) as catalysts for fine organic synthetic processes related to fine chemicals, such as flavors, pharmaceuticals, and food industries have been under attention in the last decade. The catalysts based on HPAs have many advantages over liquid acid catalysts. They are not corrosive and environmentally benign, presenting fewer disposal problems. Solid HPAs have attracted much attention in organic synthesizing owing to easy workup procedures, easy filtration, and minimization of cost and waste generation because of reusing and recycling of the catalysts $[14,15]$.

Newly some books and papers have been published which show that the synthesizing of compounds has been accelerated by ultrasound irradiation. In comparison with the traditional methods, this method is more convenient and easier to work up [16, 17].

Herein, we report a simple method for synthesizing of hydroxytriarylmethane derivatives from reaction of 2sulfobenzoeic anhydride with phenols in the presence of catalytic amounts of $\mathrm{H}_{14}\left[\mathrm{NaP}_{5} \mathrm{~W}_{30} \mathrm{O}_{110}\right], \mathrm{H}_{4} \mathrm{SiW}_{12} \mathrm{O}_{40}$ and $\mathrm{H}_{3} \mathrm{PW}_{12} \mathrm{O}_{40}$, under ultrasonic irradiation (Scheme 1). 
<smiles>O=C1OS(=O)(=O)c2ccccc21</smiles><smiles>[X]c1ccc([X])c(O)c1[X]</smiles>

(1) Heteropolyacid/ultrasonic

(2) $\mathrm{NaOH} / \mathrm{H}_{2} \mathrm{O}$<smiles>[X]C1=CC(C(c2ccccc2S(=O)(=O)[O-])c2cc([Y])c(O[NH3+])c([X])c2[Z])C([Z])=C([X])C1=O</smiles><smiles>[X]C1=CC(C(c2ccccc2S(=O)(=O)O)c2cc([Y])c(O)c([X])c2[Z])C([Z])=C([X])C1=O</smiles>

$$
\begin{aligned}
& \text { a: } X=\mathrm{H}, \mathrm{Y}=\mathrm{H}, \mathrm{Z}=\mathrm{H} \\
& \text { b: } \mathrm{X}=\mathrm{H}, \mathrm{Y}=\mathrm{H}, \mathrm{Z}=\mathrm{CH}_{3} \\
& \text { c: } \mathrm{X}=\mathrm{CH}_{3}, \mathrm{Y}=\mathrm{H}, \mathrm{Z}=\mathrm{H}
\end{aligned}
$$

$$
\begin{aligned}
& \text { d: } X=B r, Y=H, Z=H \\
& \text { e: } X=C l, Y=H, Z=H \\
& \text { f: } X=B r, Y=B r, Z=H
\end{aligned}
$$

SCHEme 1: Synthesis of hydroxytriarylmethane derivatives.

\section{Experimental}

2.1. Chemicals and Apparatus. All the chemicals were obtained from Merck, Fluka, and Aldrich Companies and were used without further purification. Melting points were measured using Thermo-Fisher Scientific. IR spectra were recorded by Bruker tensor 27, FT-IR Spectrophotometer. All ${ }^{1} \mathrm{H}$ NMR and ${ }^{13} \mathrm{C}$ NMR spectra were recorded on a Bruker 400 MHZ Spectrophotometer. Chemical shifts are reported in parts per million (ppm), using tetra methyl silane (TMS) as an internal standard. The microanalyses for $\mathrm{C}$ and $\mathrm{H}$ were performed on Perkin-Elmer elemental analyzer. The ultrasonic apparatus was the cleaning bath Wiseclear $770 \mathrm{~W}$ (Seoul, Korea). The operating frequency was $40 \mathrm{kHz}$ and the output power was $200 \mathrm{~W}$, estimated calorimetrically. The reaction flasks were located in the maximum energy area in the water bath, where the surface of reactants (reaction vessel) was slightly lower than the surface level of the water, and the addition or removal of water which controlled the temperature of the water bath. The temperature of the water bath was controlled at $55-65^{\circ} \mathrm{C}$. Silica-supported Preyssler nanoparticles were prepared according to [18].

2.2. General Procedure. A mixture of 2-sulfobenzoeic anhydride $(20 \mathrm{mmol})$, phenol derivatives $(60 \mathrm{mmol})$, and catalytic amount of heteropolyacid $(0.03 \mathrm{mmol})$ in $10 \mathrm{~mL} \mathrm{CH}_{3} \mathrm{CN}$ was irradiated under ultrasound at $55-65^{\circ} \mathrm{C}$ for required reaction time. The progress of the reaction was monitored by TLC. When the reaction was completed, the catalyst was filtered off, the solvent was evaporated under vacuum, and the product was poured into $100 \mathrm{~mL} \mathrm{NaOH} \mathrm{10 \% .} \mathrm{Then,} \mathrm{the}$ solution was acidified by $\mathrm{HCl}$. The precipitate was collected under filtration. All products were identified by their physical and spectroscopic data (Tables 1 and 2).

2.3. Recycling of the Catalyst. After filtration of the catalyst, it could be recycled, washing it with diethylether in each case. The recovered catalyst could be dried and reused for the next reaction with only a modest loss in activity. The catalyst has been recovered and reused for six times in reactions. The obtained results are summarized in Table 3.

\section{Results and Discussions}

The progress of reaction 2-sulfobenzoeic anhydride with phenols was monitored by TLC and reported yields were based on isolated products. The results showed that the highest yield of the products was achieved when $\mathrm{H}_{14}\left[\mathrm{NaP}_{5} \mathrm{~W}_{30} \mathrm{O}_{110}\right]$ was used as the catalyst.

Comparison of the catalysts in Tables 4 and 5 showed that $\mathrm{H}_{14}\left[\mathrm{NaP}_{5} \mathrm{~W}_{30} \mathrm{O}_{110}\right]$ is the catalyst of choice. Comparison of supported and nonsupported Preyssler catalyst showed that, in all cases, the supported Preyssler catalyst was less active than the nonsupported one. One plausible interpretation of this observation is that, in supported type, there are polyanion-support interactions of an acid-base nature. Some protons of the polyacid and some basic sites of the support (e.g., hydroxyl groups) can interact. This would lead to diminished availability of hydrogens because of this extra ionic 
TABLE 1: Physical and spectral data of the compounds (a-f).

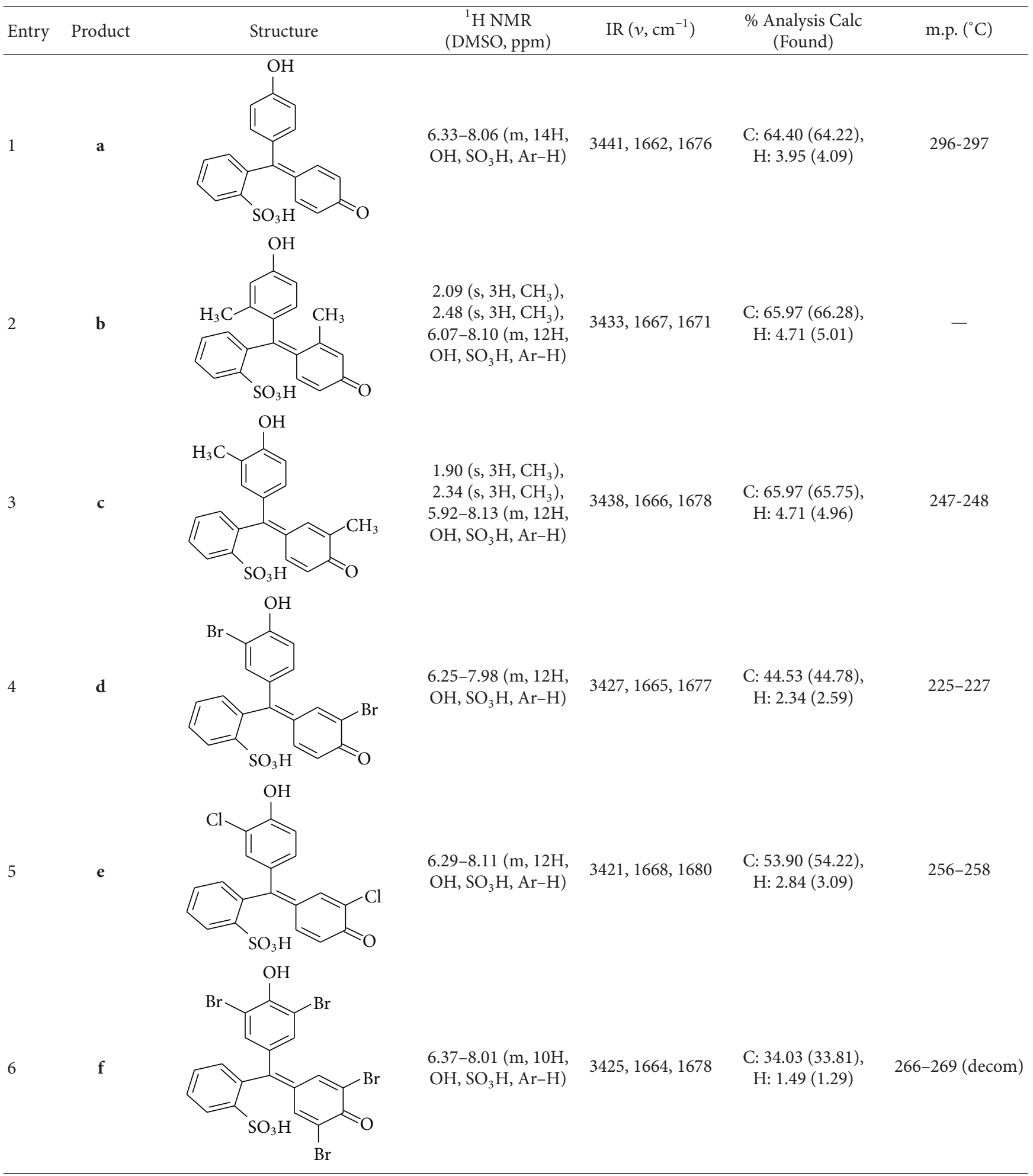

interaction [19]. Interestingly, this behavior is similar to that of Keggin heteropolyacids. However, when $\mathrm{H}_{3}\left[\mathrm{PW}_{12} \mathrm{O}_{40}\right]$ or $\mathrm{H}_{4}\left[\mathrm{SiW}_{12} \mathrm{O}_{40}\right]$ were used instead of $\mathrm{H}_{14}\left[\mathrm{NaP}_{5} \mathrm{~W}_{30} \mathrm{O}_{110}\right]$ the yield of product was slightly decreased.
The results point out that the catalytic effectiveness may be enhanced as the number of tungsten atoms (or the number of protons) is increased. Both possibilities stand to reason. In addition, the large anion also provides many "sites" on 
TABLE $2:{ }^{13} \mathrm{C}$ NMR data of the compounds (a-f).

\begin{tabular}{lcl}
\hline Entry & Product & ${ }^{13} \mathrm{C} N M R(\mathrm{ppm})$ \\
\hline 1 & a & $100.2,117.4,120.7,123.9,125.7,126.1,126.8,131.5,135.1,136.6,145.8,148.2,155.9,158.1,183.4$ \\
2 & b & $20.4,21.6,98.61,99.5,120.2,120.4,124.6,126.0,127.1,127.4,127.8,129.6,130.7,133.8,134.9,137.4,146.1$, \\
& & $152.0,154.3,155.2,181.9$ \\
3 & c & $14.2,17.5,93.2,100.2,118.9,120.6,121.1,124.7,126.7,127.5,127.7,127.9,128.7,129.9,134.2,136.1,145.3$, \\
& & $147.1,156.8,157.3,179.5$ \\
4 & d & $80.1,96.3,110.0,115.9,124.3,124.6,125.9,126.9,127.5,127.6,127.9,131.0,134.5,137.7,144.5,150.0,150.7$, \\
& & $83.2,98.8,119.4,122.2,123.1,124.8,126.1,126.9,127.4,127.5,127.8,130.5,132.0,134.1,145.9,150.0,154.3$, \\
5 & e & $155.6,175.3$ \\
6 & f & $78.9,115.9,120.0,123.9,127.4,127.6,128.4,129.0,135.6,141.1,147.7,148.2,156.0,170.1,173.3$ \\
\hline
\end{tabular}

TABLE 3: Recyclability of $\mathrm{H}_{14}\left[\mathrm{NaP}_{5} \mathrm{~W}_{30} \mathrm{O}_{110}\right]$.

\begin{tabular}{lccccccc}
\hline \multirow{2}{*}{ Entry } & \multirow{2}{*}{ Phenol } & \multicolumn{7}{c}{ Yield $(\%)^{\mathrm{a}} /$ Run } \\
& & 1 & 2 & 3 & 4 & 5 & 6 \\
\hline 1 & phenol & 95 & 93 & 90 & 88 & 86 & 84 \\
2 & $m$-cresol & 96 & 93 & 91 & 88 & 86 & 85 \\
3 & 0 -cresol & 95 & 92 & 91 & 89 & 87 & 84 \\
4 & 2-bromophenol & 93 & 90 & 87 & 86 & 84 & 82 \\
5 & 2-Chlorophenol & 94 & 91 & 90 & 88 & 85 & 83 \\
6 & 2,6-dibromophenol & 94 & 92 & 89 & 87 & 86 & 85 \\
\hline
\end{tabular}

Isolated yields.

TABLE 4: The reaction of $o$-cresol and 2-sulfobenzoeic anhydride in the presence of different catalyst at $140^{\circ} \mathrm{C}$ (time of reaction $60 \mathrm{~min}$ ).

\begin{tabular}{lcc}
\hline Entry & Catalyst & Yield $^{\mathrm{a}}(\%)$ \\
\hline 1 & $\mathrm{H}_{4} \mathrm{SiW}_{12} \mathrm{O}_{40}$ & 65 \\
2 & $\mathrm{H}_{3} \mathrm{PW}_{12} \mathrm{O}_{40}$ & 68 \\
3 & $\mathrm{H}_{14}\left[\mathrm{NaP}_{5} \mathrm{~W}_{30} \mathrm{O}_{110}\right]$ & 72 \\
4 & $\mathrm{H}_{14}\left[\mathrm{NaP}_{5} \mathrm{~W}_{30} \mathrm{O}_{110}\right] / \mathrm{SiO}_{2}$ & 35 \\
5 & $\mathrm{H}_{2} \mathrm{SO}_{4}$ & 58 \\
6 & $\mathrm{ZnCl}_{2}$ & 44 \\
\hline
\end{tabular}

TABLE 5: The reaction of $o$-cresol and 2-sulfobenzoeic anhydride in the presence of different catalysts at $55-65^{\circ} \mathrm{C}$ under ultrasonic irradiation (time of reaction $15 \mathrm{~min}$ ).

\begin{tabular}{lcc}
\hline Entry & Catalyst & Yield $^{\mathrm{a}}(\%)$ \\
\hline 1 & $\mathrm{H}_{4} \mathrm{SiW}_{12} \mathrm{O}_{40}$ & 87 \\
2 & $\mathrm{H}_{3} \mathrm{PW}_{12} \mathrm{O}_{40}$ & 90 \\
3 & $\mathrm{H}_{14}\left[\mathrm{NaP}_{5} \mathrm{~W}_{30} \mathrm{O}_{110}\right]$ & 95 \\
4 & $\mathrm{H}_{14}\left[\mathrm{NaP}_{5} \mathrm{~W}_{30} \mathrm{O}_{110}\right] / \mathrm{SiO}_{2}$ & 26 \\
5 & $\mathrm{H}_{2} \mathrm{SO}_{4}$ & 31 \\
6 & $\mathrm{ZnCl}_{2}$ & 12 \\
\hline Isolated yield. & &
\end{tabular}

the oval-shaped molecule that are likely to render the catalyst effectiveness. Interestingly, the comparison of Preyssler heteropolyacid, with its exclusive properties, with Keggin heteropolyacids, $\mathrm{ZnCl}_{2}$, and $\mathrm{H}_{2} \mathrm{SO}_{4}$ showed that the activity
TABLE 6: Comparison of efficiency of $\mathrm{H}_{4} \mathrm{SiW}_{12} \mathrm{O}_{40}, \mathrm{H}_{3} \mathrm{PW}_{12} \mathrm{O}_{40}$, and $\mathrm{H}_{14}\left[\mathrm{NaP}_{5} \mathrm{~W}_{30} \mathrm{O}_{110}\right]$ in synthesis of hydroxytriarylmethane derivatives under ultrasonic irradiation.

\begin{tabular}{lccc}
\hline Entry & Phenol & Catalyst & Yield $(\%)^{\mathrm{a}}$ \\
\hline 1 & phenol & $\mathrm{H}_{4} \mathrm{SiW}_{12} \mathrm{O}_{40}$ & 86 \\
2 & phenol & $\mathrm{H}_{3} \mathrm{PW}_{12} \mathrm{O}_{40}$ & 90 \\
3 & phenol & $\mathrm{H}_{14}\left[\mathrm{NaP}_{5} \mathrm{~W}_{30} \mathrm{O}_{110}\right]$ & 91 \\
4 & $m$-cresol & $\mathrm{H}_{4} \mathrm{SiW}_{12} \mathrm{O}_{40}$ & 88 \\
5 & $m$-cresol & $\mathrm{H}_{3} \mathrm{PW}_{12} \mathrm{O}_{40}$ & 90 \\
6 & $m$-cresol & $\mathrm{H}_{14}\left[\mathrm{NaP}_{5} \mathrm{~W}_{30} \mathrm{O}_{110}\right]$ & 94 \\
7 & $o$-cresol & $\mathrm{H}_{4} \mathrm{SiW}_{12} \mathrm{O}_{40}$ & 87 \\
8 & $o$-cresol & $\mathrm{H}_{3} \mathrm{PW}_{12} \mathrm{O}_{40}$ & 90 \\
9 & $o$-cresol & $\mathrm{H}_{14}\left[\mathrm{NaP}_{5} \mathrm{~W}_{30} \mathrm{O}_{110}\right]$ & 95 \\
10 & 2-bromophenol & $\mathrm{H}_{4} \mathrm{SiW}_{12} \mathrm{O}_{40}$ & 85 \\
11 & 2-bromophenol & $\mathrm{H}_{3} \mathrm{PW}_{12} \mathrm{O}_{40}$ & 91 \\
12 & 2-bromophenol & $\mathrm{H}_{14}\left[\mathrm{NaP}_{5} \mathrm{~W}_{30} \mathrm{O}_{110}\right]$ & 94 \\
13 & 2-chlorophenol & $\mathrm{H}_{4} \mathrm{SiW}_{12} \mathrm{O}_{40}$ & 83 \\
14 & 2-chlorophenol & $\mathrm{H}_{3} \mathrm{PW}_{12} \mathrm{O}_{40}$ & 88 \\
15 & 2-chlorophenol & $\mathrm{H}_{14}\left[\mathrm{NaP}_{5} \mathrm{~W}_{30} \mathrm{O}_{110}\right]$ & 92 \\
16 & 2,6-dibromophenol & $\mathrm{H}_{4} \mathrm{SiW}_{12} \mathrm{O}_{40}$ & 84 \\
17 & 2,6-dibromophenol & $\mathrm{H}_{3} \mathrm{PW}_{12} \mathrm{O}_{40}$ & 86 \\
18 & 2,6-dibromophenol & $\mathrm{H}_{14}\left[\mathrm{NaP}_{5} \mathrm{~W}_{30} \mathrm{O}_{110}\right]$ & 90 \\
\hline $\mathrm{a}$ & & &
\end{tabular}

Isolated yield.

TABLE 7: Synthesis of hydroxytriarylmethane derivatives using $\mathrm{H}_{14}\left[\mathrm{NaP}_{5} \mathrm{~W}_{30} \mathrm{O}_{110}\right]$ under ultra sonic irradiation.

\begin{tabular}{lccc}
\hline Entry & Phenol & Time $(\mathrm{min})$ & ${\text { Yield }(\%)^{\mathrm{a}}}^{\mathrm{a}}$ \\
\hline 1 & phenol & 20 & 91 \\
2 & m-cresol & 20 & 94 \\
3 & o-cresol & 15 & 95 \\
4 & 2-bromophenol & 25 & 94 \\
5 & 2-chlorophenol & 30 & 92 \\
6 & 2,6-dibromophenol & 40 & 90 \\
a Isolated yield. & &
\end{tabular}

for $\mathrm{H}_{14}\left[\mathrm{NaP}_{5} \mathrm{~W}_{30} \mathrm{O}_{110}\right]$ is the most. The compression of efficiency of heteropolyacids has been carried out. The results are shown in Table 6 . It is clear that $\mathrm{H}_{14}\left[\mathrm{NaP}_{5} \mathrm{~W}_{30} \mathrm{O}_{110}\right]$ gave the better yields than others. The catalytic activity is increased 
TABLE 8: Synthesis of hydroxytriarylmethane derivatives using $\mathrm{H}_{14}\left[\mathrm{NaP}_{5} \mathrm{~W}_{30} \mathrm{O}_{110}\right]$ under heating condition.

\begin{tabular}{lccc}
\hline Entry & Phenol & Time $(\min )$ & Yield $(\%)^{\mathrm{a}}$ \\
\hline 1 & phenol & 90 & 69 \\
2 & $m$-cresol & 75 & 61 \\
3 & o-cresol & 60 & 72 \\
4 & 2-bromophenol & 120 & 63 \\
5 & 2-chlorophenol & 120 & 58 \\
6 & 2,6-dibromophenol & 150 & 54 \\
\hline
\end{tabular}

Isolated yield.

in the following order: $\mathrm{H}_{14}\left[\mathrm{NaP}_{5} \mathrm{~W}_{30} \mathrm{O}_{110}\right]>\mathrm{H}_{3}\left[\mathrm{PW}_{12} \mathrm{O}_{40}\right]>$ $\mathrm{H}_{4}\left[\mathrm{SiW}_{12} \mathrm{O}_{40}\right]$.

Phenols with electron withdrawing groups gave hydroxytriarylmethane derivative in low yields. To show the merit of this method, reaction has been performed using the same catalyst repeatedly under classical heating condition. As it is shown under heating condition the higher reaction time is required. The results are shown in Tables 7 and 8 .

As ultrasound generated intense turbulence and microscale liquid circulation currents, uniform mixing at microlevel has occurred and the mass transfer resistances have been eliminated [20]. This explanation can justify the shorter reaction time observed for reactions under ultrasonic condition.

This catalyst retained its activity over six consecutive runs (Table 3).

\section{Conclusion}

We developed a new method using heteropolyacids under ultrasonic irradiation for synthesis of hydroxytriarylmethanes. The short reaction times, high yields, reusability of catalyst, and easy work up procedure are some advantages of this method.

\section{Acknowledgment}

The author thanks Payame Noor University (PNU) of Kerman for the financial support.

\section{References}

[1] R. Muthyala, A. R. Katritzky, and X. Lan, "A synthetic study on the preparation of triarylmethanes," Dyes and Pigments, vol. 25, no. 4, pp. 303-324, 1994.

[2] M. Irie, "Light-induced reversible $\mathrm{pH}$ change," Journal of the American Chemical Society, vol. 105, no. 7, pp. 2078-2079, 1983.

[3] P. J. Kocienski, Protecting Groups, Georg Thieme, Stuttgart, Germany, 3rd edition, 2003.

[4] L. Sanguinet, R. J. Twieg, G. Wiggers, G. Mao, K. D. Singer, and R. G. Petschek, "Synthesis and spectral characterization of bisnaphthylmethyl and trinaphthylmethyl cations," Tetrahedron Letters, vol. 46, no. 31, pp. 5121-5125, 2005.

[5] S. Kumar Das, Shagufta, and G. Panda, "An easy access to unsymmetric trisubstituted methane derivatives (TRSMs)," Tetrahedron Letters, vol. 46, no. 17, pp. 3097-3102, 2005.
[6] M. Yamato, K. Hashigaki, Y. Yasumoto et al., "Synthesis and antitumor activity of tropolone derivatives. 6. Structureactivity relationships of antitumor-active tropolone and 8hydroxyquinoline derivatives," Journal of Medicinal Chemistry, vol. 30, no. 10, pp. 1897-1900, 1987.

[7] N. Mibu and K. Sumoto, "Preparation of 2,2'-dihydroxytriphenylmethanes using metal phenolates with aromatic aldehydes," Chemical and Pharmaceutical Bulletin, vol. 48, no. 11, pp. 1810-1813, 2000.

[8] M. S. Shchepinov and V. A. Korshun, "Recent applications of bifunctional trityl groups," Chemical Society Reviews, vol. 32, no. 3, pp. 170-180, 2003.

[9] C. Grüttner, V. Böhmer, R. Assmus, and S. Scherf, "A convenient and general synthesis of alkanediyl diphenols," Journal of the Chemical Society, Perkin Transactions 1, no. 2, pp. 93-94, 1995.

[10] M. Gomberg, "On the preparation of triphenylchlomethane," Journal of the American Chemical Society, vol. 22, pp. 752-757, 1900.

[11] G. Casiraghi, G. Casnati, and M. Cornia, "Regiospecific reactions of phenol salts: reaction-pathways of alkylphenoxymagnesiumhalides with triethylorthoformate," Tetrahedron Letters, vol. 14, no. 9, pp. 679-682, 1973.

[12] S. Kumar Das, Shagufta, and G. Panda, "An easy access to unsymmetric trisubstituted methane derivatives (TRSMs)," Tetrahedron Letters, vol. 46, no. 17, pp. 3097-3102, 2005.

[13] L. M. Werbel, E. F. Elslager, and W. M. Pearlman, “Trisarylmethanes. Synthesis of diarylcarbinol precursors by controlled catalytic hydrogenation," Journal of Organic Chemistry, vol. 29, no. 4, pp. 967-968, 1964.

[14] M. M. Heravi, S. Sadjadi, S. Sadjadi, H. A. Oskooie, and F. F. Bamoharram, "Rapid and efficient synthesis of $4(3 \mathrm{H})$ quinazolinones under ultra sonic irradiation using silicasupported Preyssler nano particles," Ultrasonics Sonochemistry, vol. 16, no. 6, pp. 708-710, 2009.

[15] M. M. Heravi, F. Derikvand, A. Haeri, H. A. Oskooie, and F. F. Bamoharram, "Heteropolyacids as green and reusable catalysts for the synthesis of isoxazole derivatives," Synthetic Communications, vol. 38, no. 1, pp. 135-140, 2008.

[16] T. J. Mason and D. Peters, Practical Sonochemistry, Ellis Horwood, London, UK, 2nd edition, 2002.

[17] "Sonochemistry and Sonoluminiscence," in Encyclopedia of Physical Science and Technology, K. S. Suslick, Ed., vol. 17, Academic Press, San Diego, Calif, USA, 3rd edition, 2001.

[18] M. M. Heravi, S. Sadjadi, S. Sadjadi, H. A. Oskooie, R. H. Shoar, and F. F. Bamoharram, "Supported preyssler nanoparticles in synthesis of 1,3-diaryl-5- spirohexahydropyrimidines," Journal of the Chinese Chemical Society, vol. 56, no. 2, pp. 246-250, 2009.

[19] F. Lefebvre, " ${ }^{31} \mathrm{P}$ MAS NMR study of $\mathrm{H}_{3} \mathrm{PW}_{12} \mathrm{O}_{40}$ supported on silica: formation of $\left(\equiv \mathrm{SiOH}_{2}^{+}\right)\left(\mathrm{H}_{2} \mathrm{PW}_{12} \mathrm{O}_{40}{ }^{-}\right)$," Journal of the Chemical Society, Chemical Communications, no. 10, pp. 756-757, 1992.

[20] V. S. Moholkar, P. S. Kumar, and A. B. Pandit, "Hydrodynamic cavitation for sonochemical effects," Journal of Histochemistry and Cytochemistry, vol. 47, no. 5, pp. 53-65, 1999. 

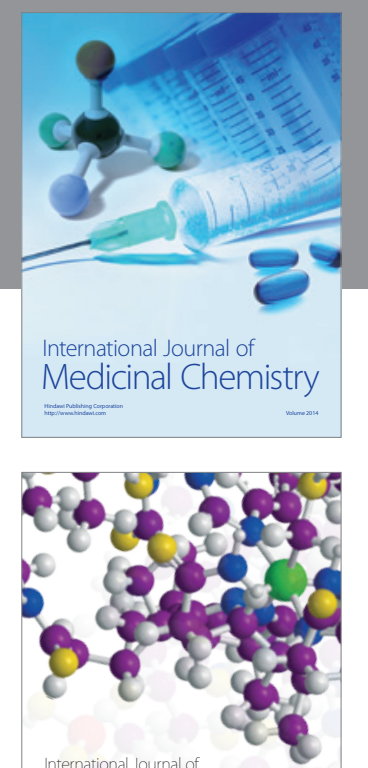

\section{Carbohydrate} Chemistry

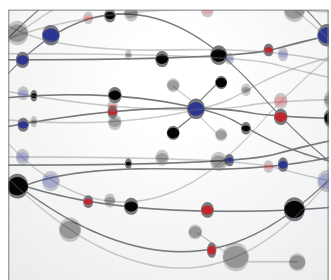

The Scientific World Journal
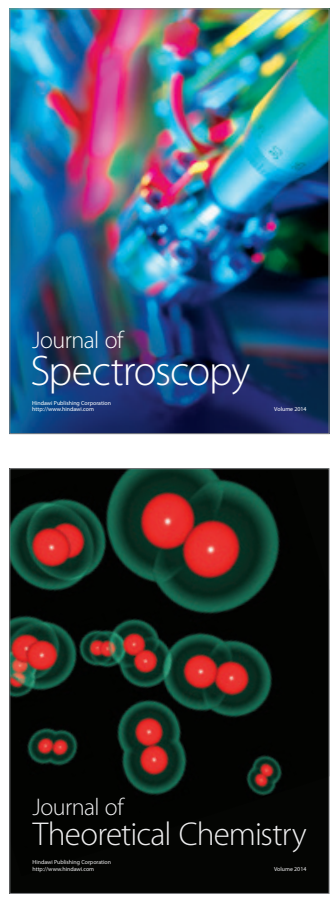
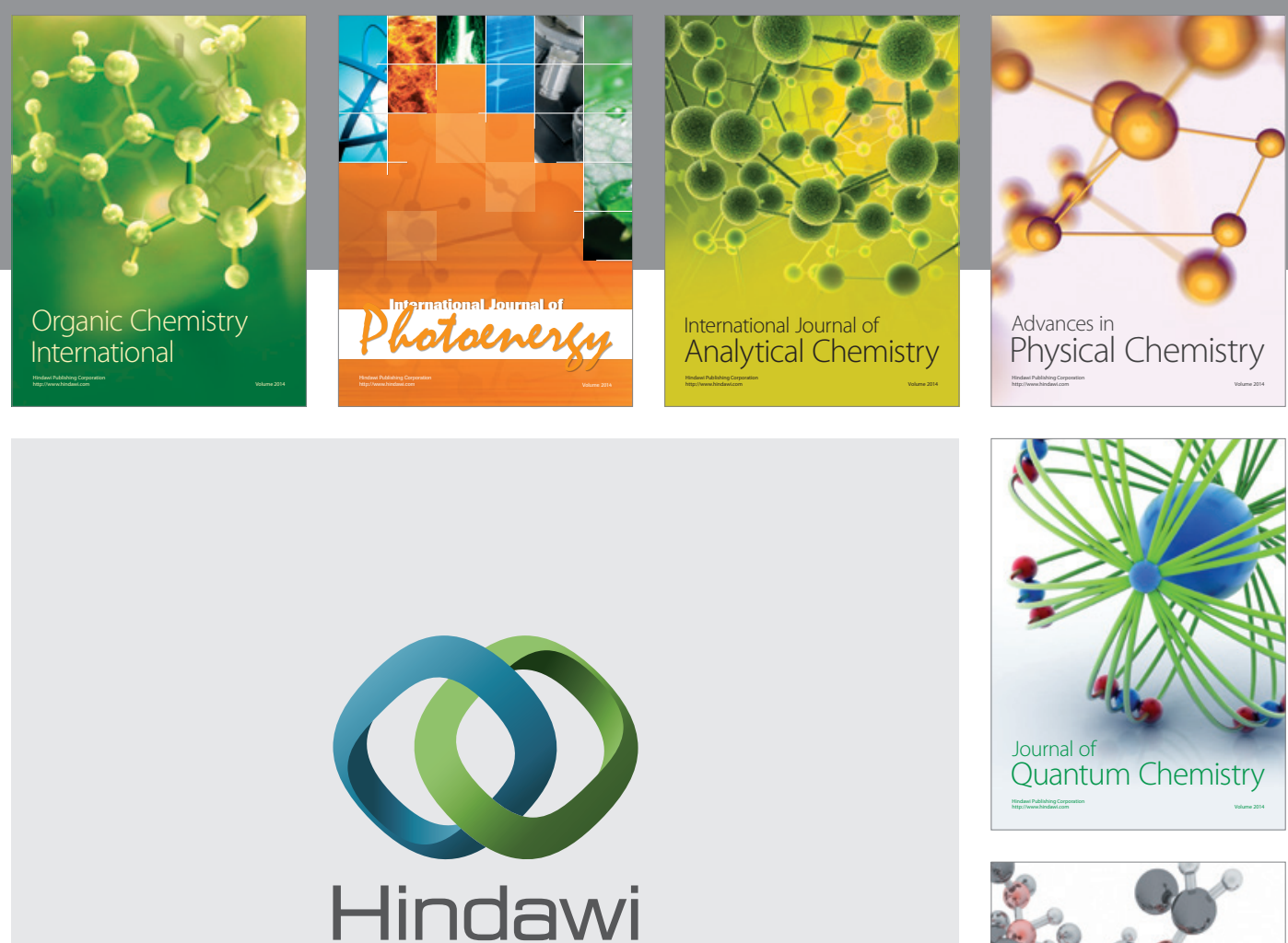

Submit your manuscripts at

http://www.hindawi.com

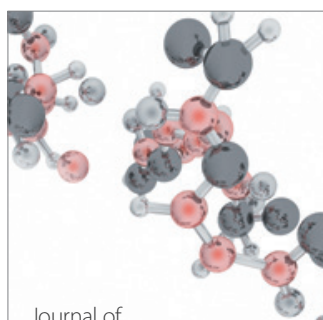

Analytical Methods

in Chemistry

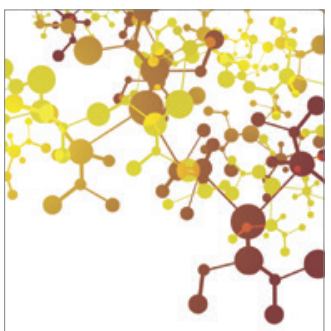

Journal of

Applied Chemistry

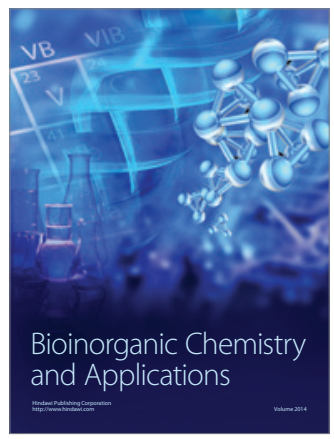

Inorganic Chemistry
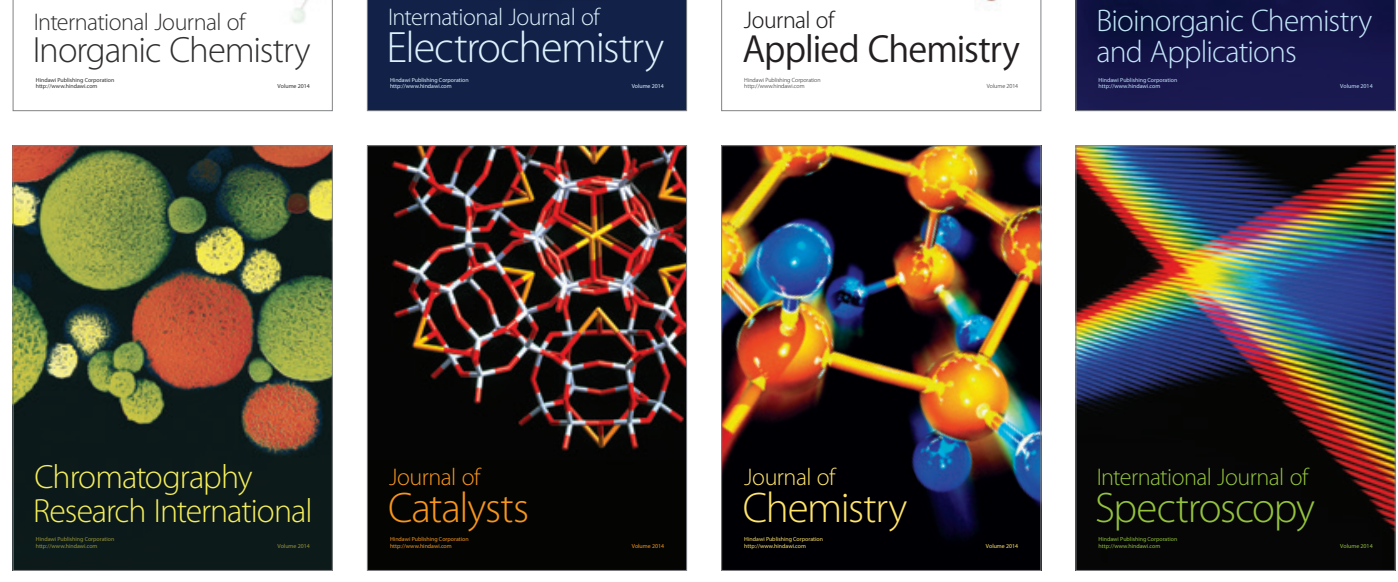